The Agriculturists 11(1): 103-111 (2013) ISSN 2304-7321 (Online), ISSN 1729-5211 (Print)

\title{
Insecticidal Activity of Some Plant Extracts Against Trogoderma granarium (E.)
}

\author{
Farooq Ahmad ${ }^{1}$, Muhammad Sagheer ${ }^{1 *}$, Ahmad Hammad ${ }^{1}$, S. M. Mizanur Rahman ${ }^{2}$ and \\ Masoor-Ul-Hasan ${ }^{1}$ \\ ${ }^{1}$ Department of Agricultural Entomology, Faculty of Agriculture, University of Agriculture, \\ Faisalabad 38000, Pakistan. ${ }^{2}$ Department of Entomology, Sher-e-Bangla Agricultural University, \\ Sher-e-Bangla Nagar, Dhaka-1207, Bangladesh.
}

*Corresponding author and Email: sagheersharif@yahoo.com

Received: 23 November 2011

Accepted: 18 May 2013

\begin{abstract}
An investigation was carried out to evaluate the insecticidal activity of Allium sativum, Zingiber officinale and Nigella sativa extracts against the larvae of T. granarium under laboratory conditions in the University of Agriculture, Faisalabad, Pakistan during 2009-10. The highest concentration of (6\%) Z. officinale was found to be comparatively more toxic (16.70\%) than those of A. sativum (10.45\%) and $N$. sativa $(5.49 \%)$ at 96 hours exposure. Regarding latent effect of the test plant materials, $Z$. officinale gave significantly higher reduction $(54.15 \%)$ in $\mathrm{F}_{1}$ progeny than $N$. sativa $(41.97 \%)$ and $A$. sativum $(32.19 \%)$. The study reveals that $Z$. officinale had a strong latent effect against the larvae of the test pest. Further investigations on the efficacy of longer exposure in combination with higher concentrations of these extracts can be helpful to reduce the wheat store-insect damage.
\end{abstract}

Keywords: Allium sativum, Insecticidal efficacy, larval mortality, latent effect, Nigella sativa, Trogoderma granarium, Zingiber officinale

\section{Introduction}

Wheat (Triticum aestivum L.) is the major and staple food of Pakistan (Ahmad, 2009). About 90 percent grains produced for daily consumption of human and animals come from cereals like wheat, rice and maize (McFarlane, 1989) while insect pests are of a great importance for major causes of grain losses during storage (Scotti, 1978). Storage of wheat on large scale is a vital component of food security where stored grains insect are causing severe damage to the stored commodities, and of course, the food insect contamination represents a crucial hurdle for export items and food industries (Rajendran, 2002). During storage, grains are destroyed by many stored-grain insect that are responsible for worldwide loss upto $10-40 \%$ annually
(Mathews, 1993). Khapra beetle, Trogoderma granarium (Everts) (Coleoptera: Dermestidae) is one of the serious storage insect pests, causing tremendous loss to stored grains in tropical regions including Pakistan (Howe, 1965 and Bell and Wilson, 1995).

Synthetic chemicals are major control measures for agricultural insect pests (Mathewes, 1993) all over the world for both field crops and postharvest protection of crops. During storage for grain protection, liquid insecticides and gases in the form of phosphine and methyl bromide have been widely used as it is cost-effective and simple method (Shaaya et al., 1997; Fields and White, 2002; Lee et al., 2004 and Islam et al., 2010). However, their constant use has caused pest resistance to insecticides, environmental 
pollution and side effects to non-target arthropods due to sub-standard techniques of fumigation that ultimately disrupt the beneficial organisms (Irshad and Iqbal, 1994; Bell and Wilson, 1995; Desneux et al., 2007 and Pimentel et al., 2009).

Botanical insecticides have long been used as attractive alternatives to synthetic insecticides for insect pest management because botanicals cause little threat to the environment or to human health (Behal, 1998 and Isman, 2006). In order to avoid the adverse effects of synthetic chemicals, recently emphasis has been given on investigating plant derivatives as grain protectants (Yang et al., 2010). Plant extracts have proved to be effective, safe, cheap, and easy to process and apply for farmers in developing countries (Belmain et al., 2001; Isman 2006 and Regnault-Roger et al., 2012). In order to make a new pesticide available and make it more successful (Copping and Menn, 2000), more than 75 plant species of different families have been tested and recorded as insecticides for stored-grain insect control (Rajendran and Sriranjini, 2008).

The ground-up root (tuberous rhizomes) of Ginger (Zingiber officinale Roscoe) has essential oils (Regnault-Roger et al., 2012) that are used as medicine since early times. Several scientists have reported its antifungal (Hasan et al., 2005 and Singh et al., 2005), antimicrobial (SaNguanpuag et al., 2011) and insecticidal properties (Ukeh, 2008 and Owolabi et al., 2009). Several chemical constituents have been reported in Z. officinale: $\alpha$-pinene, camphene, $\beta$ pinene, 1,8-cineole, linalool, borneol, $\gamma$ terpineol, nerol, neral, geraniol, geranial, geranyl acetate, $\beta$-bisabolene and zingiberene. Kalwanjii (Nigella sativa Linn.) - also known as black seed or black cumin (Rayan et al., 2011) is a member of family Ranunculaceae (Atta, 2003), and the seeds of this annual herbaceous plant are rich essential oils, fixed oils, flavonoids, saponins, alkaloids, 20\% proteins and 37\% lipids (Burits and Bucar, 2000; Al-Ghamdi, 2001 and Ali et $a l ., 2012)$. The main constituents of essential oils are thymoquinone, dithymoquinone carvacol and anethole 4-terpinole (Bruits and Bucar, 2000).

Adamu et al., (2010) reported the presence of nine volatile oils containing 2-methyl-5(1-methyl ethyl)-Bicyclo[3.1.0]hex-2-ene as the major $(62.28 \%)$ while alphapinene as the minor constituent $(2.28 \%)$. Several scientists have reported it's medicinal and insecticidal (Dashpande et al., 1974) and antimicrobial (Mashhadian and Rakhshandeh, 2005) values. Garlic (Allium sativum L.), also known as stinking rose, is a perennial pungent herb with globose bulb (Fenwicka et al., 1985). The genus, Allium (Alliaceae Family) is a very large and geographically diverse species (Khokar, 2003). It has been reported that the chief constitute of its volatile oils are allicin, 2-propene sulfenic acid, 2-propene thiol, propylene, thioacrolein and ajoene (Gurusubramaniana and Krishna, 1996) while Huang et al. (2000) have reported its two major constituents: methyl allyl disulfide and diallyl trisulfide. Several scientists have reported its antifungal and antimicrobial effect (Benkeblia, 2004) and insecticidal properties (Regnault-Roger, 1997).

The present study was conducted to evaluate the insecticidal activity of different doses of bulb extract of $A$. sativum, rhizome extract of $Z$. officinale and seed oil extract of $N$. sativa against $T$. granarium larvae.

\section{Materials and Methods}

\subsection{Insect culture}

Heterogeneous population of $T$. granarium was collected from godowns of Food Department located in Fasisalabad district of Punjab, Pakistan for rearing in the laboratory according to the procedure described by Ali et al. (2012). The study was conducted at Grain Training and Storage Management Cell, Department of Agri. Entomology, University of Agriculture, Faisalabad, Pakistan during 2007-08. The insects were kept with whole wheat grains in earthen jars (2.5-liter), covered by muslin cloth and 
tightened with rubber bands to prevent the escape of insects. The pots were kept in growth chamber in dark room at temperature (T) of $29 \pm$ $2{ }^{0} \mathrm{C}$ and relative humidity $(\mathrm{RH})$ of $70 \pm 5 \%$. After 72 hours, adult population was removed from the substrate using a standard 44-mesh sieve (pore size $2 \mathrm{~mm}$ ) and the sieved wheat grains having pest eggs were shifted to plastic containers (1-liter) covered by muslin cloth and secured by rubber bands. Five hundred $g$ of fresh sterilized wheat grains were placed as food and then these containers were kept in same climatic conditions as described above. In this way, homogeneous population of $T$. granarium was obtained after 28-32 days for further use in the experiment.

\subsection{Preparation of plant extracts}

One $\mathrm{kg}$, each of fresh rhizomes of ginger Zingiber officinale (R.), bulbs of garlic Allium sativum (L.), and $100 \mathrm{~g}$ seeds of kalwanji Nigella sativa (L.) were collected from local market in Faisalabad city. All samples were crushed using blender (Model No.WTB-110B, Jiangmen Windtech Electrical Industry Co., Ltd. China), and then electrically ground to fine powder after air drying at room temperature. The samples were stored in a clean and dry place until used. Extracts of garlic and ginger powder were obtained through rotatory shaker. For this purpose, $50 \mathrm{~g}$ powder of each sample was dipped in a flask containing $500 \mathrm{ml}$ acetone as solvent. Flasks were closed with cotton plug and aluminum foil. These flasks were placed in rotatory shaker for extraction of ginger and garlic extracts for 24 hours. The extracts were evacuated thereafter in rotatory evaporator and filtered in order to obtain the stock solution. The oil extraction of kalwanji was done by fixing flasks placed in the Soxhlet Extraction Apparatus according to Valladares et al. (1997). Ground kalwanji seeds were poured in the filter tube made by making a role of filter paper, closed from one end. There was a flask beneath this glass tube in which $500 \mathrm{ml}$ of acetone was added. This apparatus was placed on burner. The acetone was vaporized and extract was settled at the flask's bottom. Filtration was done after extraction and the extract was concentrated in the rotatory vacuum evaporator thereby getting $100 \%$ stock solution. From $100 \%$ stock solution, 2, 4 and $6 \%$ concentrations were prepared and were marked as T1, T2 and T3, respectively.

\subsection{Bioassays}

\subsubsection{Filter paper application}

Whatman No.1 filter papers were labeled with lead pencil impregnation. Each filter paper was supported on three common pins inserted into a sheet of soft pith to prevent loss of extract to the substrate during application. Each concentration was applied with the help of syringe as microapplicator. After drying, the filter papers were transferred to $80-\mathrm{mm}$ diameter glass Petridishes where these were allowed to remain overnight. Afterwards, third instar larvae were confined under inverted glass funnels on treated filter papers. The deposits on the filter paper were referred to as concentrations of solutions in a volatile solvent.

\subsubsection{Insect mortality and population build up}

Larval mortality and population build up of test insect pests against plant materials were investigated by using three concentrations as mentioned above along with acetone as control in three replications in a complete randomized design (CRD). Twenty larvae were exposed to each treatment and the same number was also confined on filter papers treated with acetone only as an untreated check. The mortality data were recorded after 24, 48, 72 and 96 hours exposure. The bioassays were conducted under the same climatic conditions as for rearing except for L14:D10 photoperiod supply. The specimens were considered dead if they failed to respond while prodding with fine paint-brush. The survivors were released on fresh grains for recording the latent effect of treatments on the population build up of test pest in $\mathrm{F}_{1}$ progeny. For this purpose, $200 \mathrm{~g}$ of sieved grains were placed in each glass jar (volume: $30 \mathrm{cc}$ ) for each 
treatment. The mouth of each jar was covered with muslin cloth and secured by a rubber band to disallow the entry of any insect in the jar. It was acclimatized in the laboratory for a period of 35 days. This part of experiment was also conducted under the same climatic conditions as for toxicity assays.

The data regarding insect mortality and population build up were subjected to one way analysis of variance (ANOVA) using statistical software, Statistix version 8.1 2005. Means of treatments were compared by LSD at $5 \%$ level of significance.

\section{Results and Discussion}

The results of the investigation regarding test plant materials, exposure time, interaction of treatments and exposure periods varied significantly. The results regarding mortality under different treatments and exposure times are given in Table 1 and Table 2, while for reduction in population build up are given in Table 3. Table 1 reveals that mortality of $T$. granarium larvae ranged from 3.17-5.49, 7.8310.45 and $13.01-16.70 \%$ at 2,4 and 6 percent concentrations in case of $N$. sativa, A. sativum and $Z$. officinale, respectively with no mortality in control treatment. The effect of treatments differed significantly from each other but the overall mortality percentage was generally very low. Larval mortality varied with concentration as it was higher in the highest concentration $(6$ $\%$ ) of each plant extract. Table 2 shows that the larval mortality varied with exposure time; at 96 hours exposure, these were $6.29 \pm 1.5,13.53 \pm 1.5$ and $22.05 \pm 3 \mathrm{SE} \%$ in case of $N$. sativa, $A$. sativum and $Z$. officinale, respectively. An appreciable decrease in population build up of $F_{1}$ progeny of $T$. granarium exposed to different treatments of $N$. sativa, Z. officinale and $A$. sativum for one month exposure was obtained in Table 3 . The reduction in population varied with concentration of each plant material; at $6 \%$ concentration it was $41.97,32.19$ and $54.15 \%$ in case of N. sativa, A. sativum and Z. officinale, respectively.
The results above revealed that mortality and latent effect on population build up of $T$. granarium in the $\mathrm{F}_{1}$ progeny varied greatly with different extracts concentrations of ginger rhizome, garlic bulb and kalwanji seed oil. Out of the three botanicals, $Z$. officinale gave comparatively higher mean mortality $(15.05 \%)$ at the maximum exposure period of 96 hours than A. sativum $(8.98 \%)$ and N. sativa $(4.27 \%)$. The maximum concentration (6 \%) caused reduction in population build up by $41.97,32.19$ and $54.15 \%$ in case of N. sativa, A. sativum and Z. officinale, respectively. The results might be useful to control the stored grain insect pests in open and closed spaces for better management. However, certain plant essential oils, like those from garlic may leave a persistent odour and when applied at a high dose could cause food to retain a strong smell and unpleasant taste (Sekou et al. 2000 and Benkeblia, 2004). So, this aspect has to be kept in mind while trying higher dose for effective results.

The repellency of $N$. sativa, A. sativum and $Z$. officinale has been studied in the past by many scientists. Shaaya et al. (1997) assessed the fumigant toxicity of a large number of essential oils extracted from various species of herb plants against several major stored-product insects. Tribolium castaneum (Herbst.) was found to be the most resistant compared with Sitophilus oryzae (L.), Rhizopertha dominica (F.) and Oryzaephilus surinamensis (L.), to most essential oils tested. With the highly active Labiatae species, Oil ZP51, a concentration of 1.4-4.5 $\mu \mathrm{l} / \mathrm{l}$ air and $24 \mathrm{hr}$ exposure time was enough to obtain $90 \%$ mortality of all the insects in space tests. In columns, $70 \%$ filled with wheat, a concentration of $50 \mu \mathrm{l} / \mathrm{L}$ and 7 days exposure period was needed to obtain 94-100\% mortality of the insects. Similar studies carried out by Yanfang et al. (1997) showed that oil of A. sativum extracted by the petroleum ether repelled adults of the $T$. granarium most efficiently at $0.2 \mathrm{ml}$ per culture dish while repellence after 72 hours was $81 \%$. 
Gulati (2007) tested the efficacy of commercially available garlic products like garlic powder, oil and garlic oil emulsion against stored grain insects and reported that all products reduced pest population by $96-100 \%$ at concentration of $0.2 \%$. Oparaeke et al. (2007) revealed that aqueous garlic bulb extracts significantly reduced the populations of the Maruca vitrata and Clavigralla tomentosicollis on cowpea compared with the untreated control. Abd ElSalam (2005) reported the garlic oil as the most effective deterrent against Callosobruchus maculates on cowpea with $100 \%$ oviposition deterrent index.

Table 1. Percent mortality of $T$. granarium larvae at different concentrations of tested plant products

\begin{tabular}{llccc}
\hline Plants & Extract & Conc. (\%) & Mortality (\%) & Average mortality (\%) \\
\hline Nigella sativa & Seeds & 2 & $* * 3.17$ & $4.27 \mathrm{c}$ \\
& & 4 & 4.17 & \\
Allium sativum & Bulbs & 6 & 5.49 & $8.98 \mathrm{~b}$ \\
& & 4 & 7.83 & \\
Zingiber officinale & Rhizomes & 6 & 8.68 & \\
& & 2 & 10.45 & $15.05 \mathrm{a}$ \\
\hline
\end{tabular}

$* \mathrm{~T}_{1}=2, \mathrm{~T}_{2}=4$, and $\mathrm{T}_{3}=6 \%$ solution of plant extracts.

**Values followed by same letter(s) are statistically identical by LSD at $5 \%$ level of significance.

Table 2. Percent mean mortality of $T$. granarium larvae at different exposures periods (4 days) of tested plant products

\begin{tabular}{ccccc}
\hline Exposure & \multicolumn{4}{c}{ Percent mean mortality \pm SE } \\
\hline hours & N. sativa & A. sativum & Z. officinale & Average \\
\hline 24 & 2.5 & 4.39 & 9.81 & 5.56 \\
48 & 3.59 & 6.53 & 12.34 & 7.48 \\
72 & 4.66 & 11.47 & 15.99 & 10.70 \\
96 & 6.29 & 13.53 & 22.05 & 13.29 \\
\hline
\end{tabular}


Table 3. Population and percent reduction of $T$. granarium over control in $\mathrm{F}_{1}$ progeny under different treatments

\begin{tabular}{|c|c|c|c|c|c|c|c|}
\hline \multirow{3}{*}{$\begin{array}{l}\text { Plant } \\
\text { Extract }\end{array}$} & \multicolumn{7}{|c|}{ Concentrations (\%) } \\
\hline & \multicolumn{2}{|c|}{$* 2$} & \multicolumn{2}{|c|}{4} & \multicolumn{2}{|c|}{6} & \multirow{2}{*}{$\begin{array}{c}\text { Control } \\
\text { Total } \\
\text { population }\end{array}$} \\
\hline & $\begin{array}{c}\text { Total } \\
\text { population }\end{array}$ & $\begin{array}{c}\% \\
\text { reduction }\end{array}$ & $\begin{array}{c}\text { Total } \\
\text { population }\end{array}$ & $\begin{array}{c}\% \\
\text { reduction }\end{array}$ & $\begin{array}{c}\text { Total } \\
\text { population }\end{array}$ & $\begin{array}{c}\% \\
\text { reduction }\end{array}$ & \\
\hline N. sativa & $* * 335.3 \mathrm{bc}$ & 20.03 & $225.0 \mathrm{ef}$ & 39.18 & $243.3 f$ & 41.97 & $419.3 a$ \\
\hline A. sativum & $360.7 b$ & 15.86 & $305.3 \mathrm{~cd}$ & 28.78 & $290.7 d$ & 32.19 & $428.7 a$ \\
\hline Z.officinale & $330.0 \mathrm{bc}$ & 20.67 & 281.3de & 32.37 & $190.7 \mathrm{~g}$ & 54.15 & $416.0 \mathrm{a}$ \\
\hline
\end{tabular}

$* \mathrm{~T}_{1}=2, \mathrm{~T}_{2}=4$, and $\mathrm{T}_{3}=6 \%$ solution of plant extracts

**Values followed by same letter(s) are statistically identical by LSD at 5\% level of significance.

\section{Conclusions}

The results of the present study have shown that the tested botanicals did not give encouraging results in contact toxicity against $T$. granarium. However, the latent effect of exposure to these botanicals gave very encouraging results, showing a significant reduction in population buildup in $F_{1}$ progeny. These results clearly indicate the need for further investigations on the efficacy of longer exposure period in combination with higher concentration that will set the stairs to create new biopesticides for stored grain insect pests management. Finally, the essential oils effect on grains quality, taste and risks to human health and environmental pollution would need to be determined before commercialization and at most, to confirm the active and stable compound present inside essential oils in order to protect the flavor of foodstuffs or stored grain from being tainted.

\section{Acknowledgements}

Financial support for this project was provided by the Endowment Fund Secretariat, Directorate of Farm Research, University of Agriculture, Faisalabad, 38000, Pakistan. We pay special thanks to Abid Ali (PhD Scholar, Institute of Plant Protection, Graduate School, CAAS, P. R. China) for providing his valuable comments on the manuscript.

\section{References}

Abd El-Salam, A. M. E. 2005. Potential of some essential and vegetable oils in protecting stored cowpea from the cowpea beetle Callosobruchus maculatus. Annals of Agricultural Science Cairo, 50(1): 283296.

Adamu, H. M., Ekanem, E. O. and Bulama, S. 2010. Identification of essential oil components from Nigella sativa seed by Gas Chromatography-mass Spectroscopy. Pakistan Journal of Nutrition, 9(10): 966967.

Ahmad, F. 2009. Food Security in Pakistan. Pakistan Journal of Agricultural Sciences, 46(2): 83-89.

AL-Ghamdi, M. S. 2001. The anti-inflammatory, analgestic and anti pyretic activity of Nigella sativa. Journal of Ethnopharmacology, 76: 45-48. 
Ali, A., Ahmad, F., Biondi, A., Wang, Y. and Desneux, N. 2012. Potential for using Datura alba leaf extracts against two major stored grains pests, the rice weevil Sitophillus oryzae and Khapra beetle Trogoderma granarium. Journal of Pest Science, 85(3): 359-366.

Ali, M. A., Abu Sayeed, M., Alam, M. S., Yeasmin, Mst. S., Khan, A. M. and Muhamad, I. I. 2012. Characteristics of oils and nutrient contents of Nigella sativa linn. and Trigonella foenum-graecum seeds. Bulletin of the Chemical Society of Ethiopia, 26(1): 55-64.

Atta, M. B. 2003. Some characteristics of nigella (Nigella sativa L.) seed cultivated in Egypt and its lipid profile. Food Chemistry, 83: 63-68.

Behal, S. R. 1998. Effect of some plant oils on the olfactory responses of rice moth, Corcyra cephalonica Stainton. Annals of Plant Protection Sciences, 6(2): 146-150.

Bell, C. H. and Wilson, S. M. 1995. Phosphine tolerance and resistance in Trogoderma granarium Everts (Coleoptera: Dermestidae). Journal of Stored Products Research, 3(3): 199-205.

Belmain, S. R., Neal, G. E., Ray, D. E. and Golop, P. 2001. Insecticidal and vertebrate toxicity associated with ethnobotanicals used as post harvest protectants in Ghana. Food Chemistry and Toxicology, 39: 287-291.

Benkeblia, N. 2004. Antimicrobial activity of essential oil extracts of various onions (Allium cepa) and garlic (Allium sativum). Lebensmittel- Wissenschaft and Technologie, 37: 263-268.

Burits, M. and Bucar, F. 2000. Antioxidant activity of Nigella sativa essential oil. Phytotherapy Research, 14: 323-328.

Copping, L. G. and Menn, J. J. 2000. Biopesticides: a review of their mode of action and efficacy. Pest Management Sciences, 56: 651-676.

Desneux, N., Decourtye, A. and Delpuech, J. M. 2007. The sublethal effects of pesticides on beneficial arthropods. Annual Review of Entomology, 52: 81-106.

Fields, P. G. and White, N. D. G. 2002. Alternatives to methyl bromide treatments for stored-product insect and quarantine insect. Annual Review of Entomology, 47: 331-359.

Gulati, R. 2007. Potential of garlic as grain protectant against Tyrophagus putrescentiae Schrank and Suidasia nesbitti Hiuges in wheat. Systematic and Applied Acarology, 12: 19-25.

Gurusubramaniana, G. and Krishna, S.S. 1996. The effects of exposing eggs of four cotton insect pests to volatiles of Allium sativum (Alliaceae). Bulletin of Entomological Research, 86: 29-31.

Hasan, M. M., Chowdhury, S. P., Alam, S., Hossain, B. and Alam, M. S. 2005. Antifungal effects of plant extracts on seed-born fungi of wheat seed regarding seed Germination, seedling health and vigour index. Pakistan Journal of Biological Sciences, 8(9): 1284-1289.

Howe, R. W. 1965. Losses caused by insects and mites in stored foods and food stuffs. Nutrional Abstract Review, 35: 285-302.

Huang, Y., Chen, S. X. and Ho, S. H. 2000. Bioactivities of Methyl Allyl Disulfide and Diallyl Trisulfide from essential oil of garlic to two species of Stored-Product Pests, Sitophilus zeamais (Coleoptera: Curculionidae) and Tribolium castaneum (Coleoptera: Tenebrionidae). Journal of Economic Entomology, 93(2): 537-543.

Irshad, M. and Iqbal, J. 1994. Phosphine resistance in important stored grain insect pests in Pakistan. Pakistan Journal of Zoology, 26(4): 347-350. 
Islam, M. S., Hasan M. M., Lei, C., MuchaPelzer, T., Mewis, I. and Ulrichs, C. 2010. Direct and admixture toxicity of diatomaceous earth and monoterpenoids against the storage pests Callosobruchus maculates (F.) and Sitophilus oryzae (L.). Journal of Pest Science, 83: 105-112.

Isman, M. B. 2006. Botanical insecticides, deterrents and repellents in modern agriculture and increasingly regulated World. Annual Review of Entomology, 51: 45-66.

Lee, B., Annis, P., Tumaalii, F., and Choi, W. 2004. Fumigant toxicity of essential oils from the Myrtaceae family and 1,8cineole against three major stored-grain insects. Journal of Stored Products Research, 40: 553-564.

Mashhadian, N. V. and Rakhshandeh, H. 2005. Antibacterial and antifungal effects of Nigella sativa extracts against $S$. aureus, $P$. aeroginosa and $C$. albicans. Pakistan Journal of Medical Sciences, 21(1):47-52.

Mathews, G. A. 1993. Insecticide application in the stores. In: Application Technology for Crop Protection. Mathews, G. A., Hislop, E. C., (eds.). CABI, London, 305-315 pp.

McFarlane, J. A. 1989. Guidelines for pest management research to reduce stored food losses caused by insect and mites. Bulletin no. 22. Overseas Development Natural Resources Institute, London, England.

Oparaeke, A. M., Dike, M. C. and Amatobi, C. I. 2007. Effect of application of different concentrations and appropriate schedules of aqueous garlic (Allium sativum L.) bulb extracts against Maruca vitrata and Clavigralla tomentosicollis on cowpea, Vigna unguiculata (L.) Walp. Archives of Phytopathology and Plant Protection, 40(4): 246-251.

Owolabi, M. S., Oladimeji, M. O., Lajide, L., Singh, G., Marimuthu, P. and Isidorov, V.
A. 2009. Bioactivity of three plant derived essential oils against the maize weevils Sitophilus zeamais (Motschulsky) and cowpea weevils Callosobruchus maculatus (Fabricius). Electronic Journal of Environmental Agriculture and Food Chemistry, 8: 828-835.

Pimentel, M. A. G., Faroni, L. R. D., Guedes, R. N. C. , Sousa, A. H. and Totola, M. 2009. Phosphine resistance in Brazilian populations of Sitophilus zeamais Motschulsky (Coleoptera: Curculionidae). Journal of Stored Products Research, 45: 71-74.

Rajendran, S. 2002. Postharvest pest losses. In: Pimentel D (ed) Encyclopedia of pest management. Marcel Dekker, Inc, New York, 654-656 pp.

Rajendran, S. and Sriranjini, V. 2008. Plant products as fumigants for stored-product insect control. Journal of Stored Products Research, 44: 126-135.

Rayan, H. Z., Wagih, H. M. and Atwa, M. M. 2011. Efficacy of Black Seed oil from Nigella sativa against murine infection with cysts of Me49 strain of Toxoplasma gondii. Parasitologists United Journal, 4(2): 165-176.

Regnault-Roger, C. 1997. The potential of botanical essential oils for insect pest control. Integrated Pest Management Review, 2: 25-34.

Regnault-Roger, C., Vincent. C. and Arnason, J. T. 2012. Essential oils in insect control: low-risk products in a high-stakes world. Annual Review of Entomology, 57: 405424.

Sa-Nguanpuag, K., Kanlayanarat, S., Srilaong, V., Tanprasert, K. and Techavuthiporn, C. 2011. Ginger (Zingiber officinale) oil as an antimicrobial agent for minimally processed produce: a case study in shredded green papaya. International Journal of Agriculture and Biology, 13: 895-901. 
Scotti, G. 1978. Les insectes et les acariens des céréales stokées. ITCF/AFNOR, Paris, 238 p.

Sekou, M. K., Charles, V., Schmit, J. P., Ramaswamy, S. and André, B. 2000. Effect of various essential oils on Callosobruchus maculates (F.) (Coleopteran: Bruchidae). Journal of Stored Products Research, 36: 355-364.

Shaaya, E., Kostjukovski, M., Eilberg, J. and Sukparkam, C. 1997. Plant oils as fumigants and contact insecticides for the control of stored product insects. Journal of Stored Products Research, 33(1): 7-15.

Singh, G., Maurya, S., Catalan, C. and De Lampasona, M. P. 2005. Studies on essential oils, Part 42: chemical, antifungal, antioxidant and sprout suppressant studies on ginger essential oil and its oleoresin. Flavour and Fragrance Journal, 20: 1-6.

Ukeh, D. A. 2008. Bioactivities of essential oils of Afromomum melegueta and Zingiber officinale both (Zingiberaceae) against Rhyzopertha dominica (Fabricius). Journal of Entomology, 5(3): 193-199.

Valladares, G., Dafago, M. T., Palacois, S. and Carpinella, M. C. 1997. Laboratory evaluation of Melia azedarach (Meliaceae) extracts against the elm leaf beetle (Coleoptera: Chrysomelidae). Journal Economic Entomology, 90: 747750 .

White, L. 1995. Chemical Control: Integrated management of insects in stored products. Dekker Inc.; New York, 287-330 pp.

Yanfang, G. U., Shang, F. D. and Xue, J. 1997. The repellency of six plant substances to adult Tribolium castaneum (Herbst.). Acta Agriculturae Universitatis Henanensis, 31(3): 277-279.

Yang, F. L., Zhu, F. and Lei, C. L. 2010. Garlic essential oil and its major component as fumigants for controlling Tribolium castaneum (Herbst) in chambers filled with stored grain. Journal of Pest Science, 83: 311-317. 